\title{
CHUNKING STRATEGY; IN ENHANCING FOURTH SEMESTER STUDENTS' READING SKILL AT ENGLISH DEPARTMENT OF MUHAMMADIYAH UNIVERSITY
}

\author{
\#1 Jusmin HJ Wahid, "2 Iswan A. Thais \\ ${ }^{\# 1}$ English Lecturer, Faculty of Education, Muhammadiyah University of North \\ Maluku, Indonesia \\ ${ }^{* 2}$ English Lecturer, Faculty of Teknnique, Akademi Ilmu Komputer (AIKOM) \\ Ternate, Indonesia
}

Corresponding Author Email: j.hj.wahid2010@gmail.com

\begin{abstract}
A B S T R A C T S
Teaching reading skill to the students needs applying the appropriate strategy to stimulate students' understanding to meet the main purpose in the teaching and learning process. It was expected that the strategy itself should be able to be used by the teacher to design the better ways for the students in order to acquire important information. It is realized that many students now need as much information as possible in comprehending all the texts they read. To overcome this problem, the researcher used chunking strategy to improve students' reading skill. The researcher used true experiment to design this research, then the pre-test was used to find out whether this group in the same level and the posttest was used to detect the progress of the students. The total numbers of the students who involved in the pre-test and post-test were 20 . The data showed that the information in the post-test that; mean score was 70.50, and the pre-test got score was 61.85 then the standard deviation in the post-test was 10.32 and the standard deviation in pre-test is 8.27. It could be concluded that the students get significant progress in their understanding of reading skill by using Chunking strategy in English Department.
\end{abstract}

\author{
A R T I C L E I N F O \\ Article History: \\ Received: May, 2020
}

Revised: June, 2020

Published: June, 2020

Keywords:

Chunking Strategy,

Reading Skill,

How to cite: HJ Wahid, J., \& A. Thais, I. (2020). Chunking Strategy; in Enhancing Fourth Semester Students' Reading Skill at English Department of Muhammadiyah University. Jo-ELT (Journal of English Language Teaching) Fakultas Pendidikan Bahasa \& Seni Prodi Pendidikan Bahasa Inggris IKIP, 7(1), 18-25. doi:https://doi.org/10.33394/jo-elt.v7i1.2636

\section{INTRODUCTION}

Reading refers to the process or activity of how to look for requiring and developing knowledge from a message or a text given. So, the teacher of English who teaches reading skill to students should be able to choose and apply appropriate strategy in order to the students might require what they need as the objective in the teaching and learning process.

Teaching reading skill to the students is very difficult thing. It might come from the teachers who do creative things to stimulate the teaching reading itself, so it can be made the students' interest in reading. In line with, another difficulties come up from the students who did not interest to read a long passage so it also makes the students do not understand about the passage they have read. The lack of vocabulary, and understanding the meaning of what they have read it makes them difficult to understand all passage that they have read. 
Now, many students need as much information as possible in a short time, so that all changes can be known immediately. For example, because of increasing and improving reading skill, the students can know everything. On the words, by reading skill, students could hone their thinking patterns, and change the character of students.

In reading itself has a strategy, so that all reading can be absorbed properly and quickly, reading can be through electronic media and printed medians. To find out from some of the science and other information, it is necessary for the students to read. Because of reading, students can get new information and can improve their understanding of reading skill. Students sometimes lack clarity in understanding a text or require a substantial of idea, to comprehend it students must mastery a lot of vocabulary and get a good understanding of the text to exposure it.

A number of processes that take place during the reading of a text. There is vocabulary and understanding the text processing, understanding sentences based on chunking strategy, and need to comprehend about the sentences meaning. The use of chunking will help the students understand the provisional structure of a text and then they can be restructuring and organizing the content of each sentence.

To make the atmosphere in the teaching and learning process active, the teacher and lecturer need a good strategy to make the students comfortable in attention to the material about reading. In line with, the researcher interests in chunking strategy in improving students' understanding in reading skill. By using this strategy, the researcher does hope the students could improve their understanding in reading skill.

Based on the above background, the researcher stated some problems that students have were lack of vocabulary, lack of understanding of the passage, and lack of interest in reading.

Bojovic (2010) a reading skill is a cognitive ability which a person is able to use when interacting with the written text. In the taxonomies given in the following paragraph some skills seem more inclusive than others. Reading skills involve: identifying word meaning, drawing inferences, identifying writer's technique, recognizing mood of passage, finding answers to questions. Reading skills also include: recognizing the script of language; deducing the meaning, use of unfamiliar lexical items; understanding explicitly and nonexplicitly stated information, conceptual meaning, communicative value of sentences, relations within the sentences and between parts of text through lexical cohesion devices; recognizing indicators and main point of information in discourse; distinguishing main idea from supporting detail; selective extraction of relevant points from the text; basic reference skills; skimming, scanning, transcoding information from diagrams/charts. Ismail (2017 in Nunan, 1999) defines reading as a process of reconstructing meaning rather than decoding form, and the reader only resorts to decoding if other means fail. Moreilon (2007) states that reading is making meaning from print and visual information. But reading is not simple. Reading is an active process that requires a great deal of practice and skill. Reading is a fluent process of reader combining information from a text and their own background knowledge to build meaning (Nunan, 2003).

Iksan (2017) teaching reading is an important activity done by the teacher in the classroom. It is an activity to help the students learn to read some words and sentences by giving knowledge about the meaning of the text. It is started by teaching students how to find the topic, main idea, as well as understand the meaning in all paragraphs in the text. The teacher should guide the students to understand and comprehend the meaning of the text and get some new knowledge from the written text.

Wallace (1992) states that teaching reading is the process in English classroom where there is an interaction between the teachers and the students; the teacher guides the students to get meaning from the text passage. Linse (2005) argues that teaching reading comprehension is teaching students how to derive meaning as well as analyze or synthesize what they have 
read. It indicates that teaching reading comprehension means not only teaching the students how to read well but also teaching them how to gain a deep understanding of what they read. The teacher also teaches the students how the way to comprehend and catch the meaning of the text. It helps the students to understand to get the meaning of the passage.

In teaching reading, three main activities should be considered by the teacher. Brown (2007) argues that the activity of teaching reading includes: (1) Pre-reading activity, in this activity the students do not come into the reading activity yet, the teacher tries to activate students' knowledge about the topic being discussed. The students are lead to recognize the topic and some stated information through skimming and scanning activities. The students are also guided to be familiar with some vocabulary included in the reading text. This activity is done only to attract students' interest, motivation, and enthusiasm until the end of reading activity. (2) Whilst-reading activity, this activity is usually assumed as the core of the reading process. The students start to read the text and comprehend all information in the text. The students are also guided to identify main ideas on each paragraph, grasp all information comprehensively and try to make some clues of the vocabularies. In this activity, the teacher encourages the students to focus on reading, so that the students will be easy to understand and know what they have read so far. (3) Post-reading activity, it is the end of the reading section. In this activity, the teacher tries to evaluate the students' comprehension of the reading text. The valuation includes vocabulary, grammatical, meaning, and summarizing of the author's purpose. In addition, to know these items, the teacher gives an exercise toward the students.

Parmawati and Rasi (2017 in Burns 1996) divides reading comprehension into four levels. They are: literal comprehension, interpretive comprehension, critical reading, and creative reading. The basis ofliteral comprehension is recognizing stated main ideas, details causes and effect, and sequences. It is important because it is a prerequisite for higher level of understanding. The second level is interpretive comprehension. Here, the skill include : (1) inferring the main ideas of passage in which the main idea are not directly stated; (2) inferring the cause and effect relationship when they are not directly stated; (3) inferring referent of pronouns; (4) inferring referent of adverb; (5) inferring the omit words and (6) drawing conclusion. The third is critical reading. It is evaluating written material, comparing the ideas discovered with known standard and drawing conclusion about their accuracy, appropriateness and timeliness. The critical reading must be an active reader, questioning, searching for the facts, and suspending the judgment until he or she considered all materials. The last level is creating reading. It involves going beyond the material presented by authors. It requires readers to think as they read. To help the students acquire the skill of reading creatively, lecturers should model the thought process involved.

Chunking is a strategy or process by which one can efficiently increase the amount of information that can be stored in short term memory by reorganizing information in a meaningful way, or by finding pattern within a set of items to be remembered. Chunking is arguably one of the most powerful ways to increase the amount of information that can be stored in memory. Miller (1956) a process of grouping or organizing input information into meaningful units or chunk. Because the information in immediate memory is limited to approximately seven items, grouping items together in a way that allows them to be more easily remembered can effectively increase the amount of information that can be stored, eventually, and recalled. Gobet and Lane (2017) a chunk is a meaningful unit of information built from smaller pieces of information, and chunking is the process of creating a new chunk. Thus, a chunk can be seen as a collection of elements that have strong associations with one another, but weak associations with elements belonging to other chunks. Chunks, which can be of different sizes, are used by memory systems and more generally by the cognitive system. Che Lah et al in Afflerbach et al, (2008). Chunking strategy is a cognitive strategy 
applied to enhance mental performance. It involves the reorganizing of bulk information into various smaller chunks without adding or subtracting the quantity of new information being acquired. Reorganization of information occurs at the pattern-finding level within the set of items to be stored in STM.

Che Lah et al in Afflerbach et al, (2008) Chunking is a significant learning strategy aimed at overcoming Short Term Memory (STM) limitations. Miller (1956) characterized chunking as a process of combining different items into a meaningful larger unit that facilitates item storage in STM. The chunking strategy reduces cognitive overload, therefore, increasing the learner's mental storage capacity. For instance, in learning how to spell H-O-R-S-E, five storage units in the STM are required. However, if a learner associates the meaning of 'HORSE' to the animal itself, he or she would only need one storage unit. The strategy moves up to a higher assistive rank if the learner conjures up a schema, or associates the word with background knowledge of the animal.

According to West, Farmer, and Wolff (1991), chunking strategy is a mental process grouped into three categories: linear chunking, taxonomic, and multipurpose. Linear chunking is information arranged into time, space, or process as controlled by the historical chronology. Taxonomic chunking is the process of arranging information as observed in Bloom's Taxonomy for cognitive domain, whereas the multipurpose chunking involves the mechanism of arranging based on either the volume or the lack of information learned.

Three chunking strategies were identified in this study: mixed chunking, similar chunking, and characteristic chunking. Mixed chunking entails an information reduction process which sees large piece of information reduced into smaller and more manageable information chunks containing different numbers of elements. Similar chunking consists of separating information into similar elements, whereas characteristic chunking is influenced by elements of similar pronunciation or other characteristics providing strong connection to each other.

\section{RESEARCH METHOD \\ Research Design}

This research used true experimental design, than the researcher used randomized in pre test and post test to emphasize objective measurements and the statistical, mathematical, or numerical analysis of data collected through by manipulating pre-existing statistical data using computational techniques.

\section{Population and Sample}

Population of this researchs are all students of fourth semester at English Department of Muhammadiyah University; consists of two classes, namely class A consists of 44 students and B consists of 42 students. Then, the researcher used Random sampling to take the sample in class A. The researcher measures that reaction of both groups and giving only one treatment, the researcher can conclude that any differences in the reactions of the groups are due to the treatment alone.

\section{Instruments}

The instruments of this research are multiple choice consist of 20 questions for reading text on pre-test and post-test. The pre test is used to find out whether this group is in the same level and the post-test is used to detect the progress of the students.

\section{Data Analysis}

Data analyzing technique is SPSS-16 to continuation process from data processing to observe how to interpret the data, and analyze the data from output which have in output phase of 
the data tabulation . Prasetyo (2005) The researcher tries to describe the steps in collecting data of the investigation. In this technique of analysis data, the researcher uses the research:

a) The mean formula

The mean is used to find out the average scores. It is efficient measurement of control tendency.

b) The standard deviation formula

The standard deviation is used to average variability of all the score around the mean.

c) Categorization

To find out criteria of the students skill in understanding reading.

\section{RESEARCH FINDINGS AND DISCUSSION} Research Findings

Based on the result of pre-test on students' competence in reading text by using chunking strategy can be shown in their mean and standard deviation, it can be seen at table 1:

Table 1

Paired Samples Statistics t-test

\begin{tabular}{|c|c|c|c|}
\hline & Mean & N & Std. Deviation \\
\hline Understanding of reading in pre-test & 61.8500 & 20 & 8.27345 \\
\hline Understanding of reading in post-test & 70.5000 & 20 & 10.32371 \\
\hline
\end{tabular}

The total number of students who belong to the pre-test class was 20 . The data gives information in the post-test that; mean score is 70.50, and the pre-test got score was 61.85, then the standard deviation in the post-test was 10.32 and the standard deviation in the pre-test is 8.27. It can be concluded that the students get significant improvement in their understanding of reading skill by using Chunking strategy in English Department.

Table 2

The normality test

\begin{tabular}{|c|c|c|c|}
\hline Class & Kolmogorov-Smirnov & Df & Sig \\
\hline Post test & 1.817 & 20 & .517 \\
\hline Pre test & 1.717 & 20 & .683 \\
\hline
\end{tabular}

Based on the table 2, it can be concluded that the data of the pre-test and post-test were normal. It is because the value of significance is higher than 0.05 . It can be seen from Kolmogorov-Smirnov table in which the significance value of the pre-test was $1.717>0.05$ and the post-test was $1.817>0.05$, it shows that the data in this research was normal.

Table 3

Data distribution pre-test by using Chunking Strategy

\begin{tabular}{|l|l|l|l|l|l|}
\hline \multicolumn{2}{|l|}{} & Fr & P & $\begin{array}{l}\text { Valid } \\
\text { Percent }\end{array}$ & $\begin{array}{l}\text { Cumulative } \\
\text { Percent }\end{array}$ \\
\hline V & $\mathbf{5 0}$ & 3 & 15.0 & 15.0 & 15.0 \\
\hline & $\mathbf{5 6}$ & 5 & 25.0 & 25.0 & 40.0 \\
\hline & $\mathbf{6 0}$ & 3 & 15.0 & 15.0 & 55.0 \\
\hline & $\mathbf{6 5}$ & 3 & 15.0 & 15.0 & 70.0 \\
\hline & $\mathbf{7 0}$ & 4 & 20.0 & 20.0 & 90.0 \\
\hline & $\mathbf{7 5}$ & 1 & 5.0 & 5.0 & 95.0 \\
\hline & $\mathbf{7 7}$ & 1 & 5.0 & 5.0 & 100.0 \\
\hline & Total & $\mathbf{2 0}$ & $\mathbf{1 0 0 . 0}$ & $\mathbf{1 0 0 . 0}$ & \\
\hline
\end{tabular}

In table 3, the researcher used percentage to explain more about the students score in every point, it can be seen that 3 students frequently got 50 score or $15.0 \%, 5$ students frequently got score 56 or $25.0 \%, 3$ students frequently got score 60 or $15.0 \%, 3$ students 
frequently got score 65 or $15.0 \%, 4$ students frequently got score 70 or $20.0 \%$, 1 student frequently got score 75 or $5.0 \%$, and 1student frequently got score 77 or $5.0 \%$ it can be stated that students' understanding in reading skill was still low.

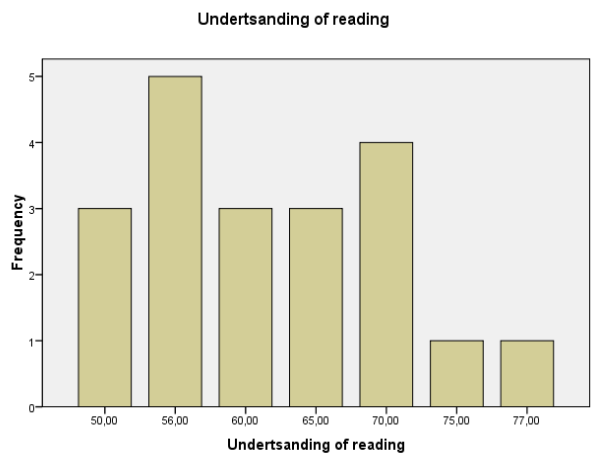

Figure 1. Diagram of Pre-test

Table 4

Data distribution post test by using Chunking strategy

\begin{tabular}{|l|l|l|l|l|l|}
\hline \multicolumn{2}{|l|}{} & Fr & Pr & V Pr & $\begin{array}{l}\text { Cumulative } \\
\text { Percent }\end{array}$ \\
\hline V & $\mathbf{5 5}$ & 1 & 5.0 & 5.0 & 5.0 \\
\hline & $\mathbf{5 7}$ & 1 & 5.0 & 5.0 & 10.0 \\
\hline & $\mathbf{6 0}$ & 3 & 15.0 & 15.0 & 25.0 \\
\hline & $\mathbf{6 5}$ & 2 & 10.0 & 10.0 & 35.0 \\
\hline & $\mathbf{6 7}$ & 4 & 20.0 & 20.0 & 55.0 \\
\hline & $\mathbf{7 0}$ & 2 & 10.0 & 10.0 & 65.0 \\
\hline & $\mathbf{8 0}$ & 4 & 20.0 & 20.0 & 85.0 \\
\hline & $\mathbf{8 5}$ & 2 & 10.0 & 10.0 & 95.0 \\
\hline & $\mathbf{9 0}$ & 1 & 5.0 & 5.0 & 100.0 \\
\hline & Total & $\mathbf{2 0}$ & $\mathbf{1 0 0 . 0}$ & $\mathbf{1 0 0 . 0}$ & \\
\hline
\end{tabular}

In table 4, the researcher used percentage to explain more about the students score in every point, it can be seen that 1 student frequently got 55 score or $5.0 \%, 1$ student frequently got score 57 or $5.0 \%, 3$ students frequently got score 60 or $15.0 \%, 2$ students frequently got score 65 or $10.0 \%, 4$ students frequently got score 67 or $20.0 \%, 2$ students frequently got score 70 or $10.0 \%$, 4 students frequently got score 80 or $20.0 \%, 2$ students frequently got score 85 or $10.0 \%$, and 1 student frequently got score 1 or $5.0 \%$. It strongly improved that after treatment the students more seriously and do attention in reading skill by using chunking strategy so they get significant improvement in their understanding of reading skill through chunking strategy.

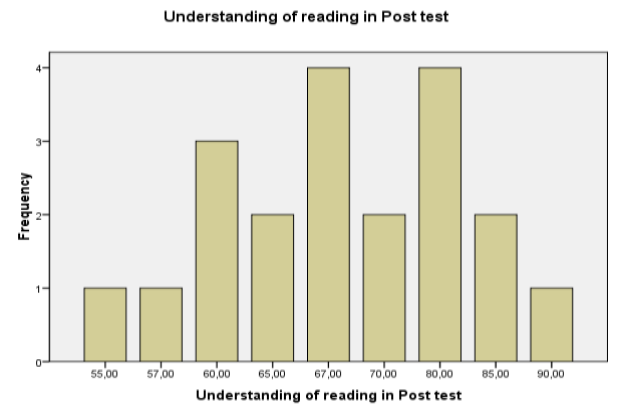

Figure 2. Diagram of Post-test 


\section{Discussion}

The students got significant improvement after treatment based on chunking strategy, it shows on diagram above that the students got 70.50 and the standard deviation was 10.32 it can be concluded that the students got good understanding on reading skill.

Based on the analyses above the researcher concludes that the test result and the effectiveness of using chunking strategy in teaching reading skill can be effectively well. And than chunking strategy is an effective strategy in teaching reading skill in classroom. It proved from the result of pre test was 61.85 and post test was 70.50 in the class which showed that there is significant different in students score in pre test and post test of English Program at Muhammadiyah University of North Maluku.

It can bees on the previous study that the results of this study showed that the use of chunking strategy was effective to use in learning process to teach reading comprehension. It could be seen from the improvement of students' score of pre-test and post-test had improved. Furthermore, relating to the research findings, the conclusion are presented as follows: 1). Chunking strategy was effective and good strategy to use in teaching reading comprehension because this strategy help students understand and remember the information easily; 2). Utilizing chunking strategy could improve the students' achievement and could overcome the students' problem (lack of vocabulary and misunderstanding of words); 3). Chunking Strategy could encourage the students' motivation and involvement in the class; 4). Achievement was influence by students' attitude. Having good attitude will get a good achievement. Therefore, students should maintain their attitude for getting a good achievement during learning process. (Rini Angraeini, 2015)

\section{CONCLUSION}

Chunking strategy can improve the students' understanding on reading skill in English teaching process and making the students attracted in teaching learning process because they can achieve their learning goal. The students at English department of Muhammadiyah university also are interested in this strategy because they got a lot of information suha as vocabulary and improve their understanding in the text.

\section{REFERENCES}

Afflerbach, P., Pearson, P. D., \& Paris, S. H. (2008). Clarifying Differences between Reading Skills and Reading Strategies. The Reading Teacher, 61(5), 364-373.

Bambang, P. (2005). Metode penelitian kuantitatif: teori dan aplikasi. Raja Grafindo Persada. Brown, H. D. (2007). Language assessment principles and classroom practice. New York: Pearson Education, Inc.

Che Lah, N., Saat, R. M., \& Hassan, R. (2014). Cognitive Strategy In Learning Chemistry: How Chunking And Learning Get Together. The Malaysian Online Journal of Educational Science. 2(1), 9-15.

Creswell, W. J. (2008). Educational Research: Planning, Conducting, and Evaluating Quantitative and Qualitative Research. United States of America: Pearson Education.

Gobet, F., \& Lane, P. C. R. (2017). Chunking Mechanisms And Learning. Department of Psychology, Brunel University \& School of Computer Science: University of Hertfordshire.

Ikhsan, M. K. (2017). The Alternative Strategies For Teaching Reading Skill For EFL Students. Unpublished Thesis. STKIP PGRI Sumatera Barat.

Ismail, H, S, J ,K., \& Basuki. (2017). Improving the students' Reading Skill Through Translation Method. Journal of English Education, 2(2), 124-131.

Linse, C. T. (2005). Practical English language teaching: Young learners. New York: Mc. Graw-Hill Companies, Inc. 
Miller, G. A. (1956). The Magical Number Seven Plus Or Minus Two: Some Limits On Our Capacity For Processing Information. Psychological Review, 63, 81-97.

Moreilon, J. (2007). Collaborative Strategies for Teaching Reading Comprehension. Chicago: American Library Association.

Nunan, D. (2003). Practical English Language Teaching. North America: McGraw Hill/Contemporary.

Nunan, D. (1999). Second Language Teaching and Learning. Masschyserts: Heinle and Heinlepulicher.

Rini, A. (2015). The effectiveness of using chunking strategy to improve students' reading comprehension at the second year of smp negeri 2 barombong. English Education Department of UIN Alauddin Makassar.

Van Dijk, T. A., \& Kintsch, W. (1983). Strategies of Discourse Comprehension. New York: Academic Press.

Wallace, C. (1992). Language teaching: A schemata for teaching education. New York: Oxford University.

West, C., Farmer, J., \& Wolff, P. (1991). Instructional design: Implications from cognitive science. Englewood Cliffs, NJ: Prentice Hall. 